\title{
Proceeding Paper \\ ERA-MIN: A Decade since the Inception of the EU Led Effort to Support the International Raw Materials Research Community ${ }^{\dagger}$
}

\author{
Julio Marchamalo $^{1, * \mathbb{C}}$, Jorge Sotelo ${ }^{1}$ and Dina Carrilho ${ }^{2}$ \\ 1 The Spanish Foundation for Science and Technology (FECYT), 28100 Madrid, Spain; jorge.sotelo@fecyt.es \\ 2 The Foundation for Science and Technology (FCT), 1249-074 Lisbon, Portugal; dina.carrilho@fct.pt \\ * Correspondence: julio.marchamalo@fecyt.es \\ + Presented at International Conference on Raw Materials and Circular Economy, Athens, Greece, \\ 5-9 September 2021.
}

\begin{abstract}
ERA-NET Cofund on Raw Materials (ERA-MIN) is a global, innovative and flexible panEuropean network of research funding organisations, supported by EU Horizon 2020, that counts now with its third edition. ERA-MIN3 (2020-2025) builds on the experience of the FP7 ERA-NET ERA-MIN (2011-2015) and the still running H2020 ERA-MIN 2 (2016-2022). ERA-MIN aims to support the European Innovation Partnership on Raw Materials (EIP RM), the EU Raw Materials Initiative, the Circular Economy Action Plan and further develop the raw materials (RM) sector in Europe through funding of transnational research and innovation (R\&I) activities. This is achieved through calls designed and developed specifically for the non-fuel, non-food raw materials sector.
\end{abstract}

Keywords: metallic minerals; construction materials; industrial minerals; circular economy; critical raw materials; research funding; international cooperation

Citation: Marchamalo, J.; Sotelo, J.; Carrilho, D. ERA-MIN: A Decade since the Inception of the EU Led Effort to Support the International Raw Materials Research Community. Mater. Proc. 2021, 5, 110. https:// doi.org/10.3390/materproc2021005110

Academic Editor: Konstantinos Simeonidis

Published: 28 January 2022

Publisher's Note: MDPI stays neutral with regard to jurisdictional claims in published maps and institutional affiliations.

Copyright: (c) 2022 by the authors. Licensee MDPI, Basel, Switzerland. This article is an open access article distributed under the terms and conditions of the Creative Commons Attribution (CC BY) license (https:// creativecommons.org/licenses/by/ $4.0 /)$.

\section{Introduction}

ERA-MIN is one of the many Public-Public Partnerships (P2Ps) in research and innovation that aims to establish networks of public research funding organizations (ministries, funding agencies and programme managers) from EU Member States and other countries, that come together to efficiently design and support a common vision of research and innovation activities. The main goal of P2Ps is to align national strategies to come with a more efficient approach and avoid the fragmentation of public research effort. P2Ps include partnerships supported by the European Commission (EC) such as ERA-NETs and Art 185s and also Member State-led initiatives, known as Joint Programming Initiatives.

ERA-MIN is one of the close to 200 ERA-NETs, which are networks of national and regional research funding organizations and ministries that join forces to design and implement thematic research and innovation programmes to fund transnational projects through joint, open and competitive calls. The first ERA-NETs, created during the 6th Framework Programme of the EC, helped to coordinate national/regional research strategies by supporting the implementation of joint calls for transnational proposals.

In the 7th Framework Programme, when the first project of ERA-MIN started, the ERA-NET scheme was reinforced by ERA-NET Plus, which in some specific priority sectors allowed the topping-up of joint trans-national funding for calls with European Union funding. After this successful pilot, in Horizon 2020 the ERA-NET Cofund instrument merged the former ERA-NET and ERA-NET Plus into a single instrument that required implementing one substantial call with top-up funding from the EC on each of its initiatives. Thus, the focus of ERA-NETs shifted from the funding of networks to the top-up funding of joint calls. Currently there are 66 active ERA-NET Cofund networks amongst a total of 265 P2Ps created since 2002 [1]. Both ERA-MIN 2 and ERA-MIN3 correspond to the ERA-NET Cofund scheme type and are coordinated by FCT-Foundation for Science and Technology in Portugal. 


\section{The EU Raw Materials Policy Context}

The importance of raw materials (RM) and its related key enabling technologies are essential for Europe's and the World's industrial future. Several strategic documents have been developed in the past decade, since 2008, when the Commission adopted the medium- to long-term integrated EU strategy covering non-energy and non-agricultural raw materials: the "Raw Materials Initiative built in 3 pillars: international, domestic and recycling [2].

All RM policies aim to guide the raw materials sector to more sustainable, efficient and cleaner technological innovations that guarantee the raw material cycle to keep driving the world's economy for many more years to come.

At a global level, the 2030 Agenda for Sustainable Development [3] and its 17 Sustainable Development Goals incorporate some the key objectives the raw material community looks to support. Specifically, technological innovation is at the foundation of the efforts undertaken to achieve the environmental and growth set by the general assembly of the United Nations and also an integral part of the ERA-MIN goals objectives (mainly SDG6 (Ensure Availability and Sustainable Management of Water and Sanitation for All), SDG7 (Ensure Access to Affordable, Reliable, Sustainable and Modern Energy for All), SDG9 (Build Resilient Infrastructure, Promote Inclusive and Sustainable Industrialization and Foster Innovation), SDG 17 (Strengthen the Means of Implementation and Revitalize the Global Partnership for Sustainable Development) and particularly SDG 12 (Ensure Sustainable Consumption and Production Patterns). In that respect, importance is brought to energy and resource-efficient technologies for mining and mineral processing, as well as secondary raw material supply via recycling. Additionally, end-of-life products re-use and recycling, and the development of innovative processes for production and remanufacturing, in the context of life-cycle analysis and new business models are some of the objectives that many of the ERA-MIN projects have at their core.

At a European level, the Circular Economy Action Plan draws measures that cover the whole life cycle: from production and consumption to waste management and the market for secondary raw materials. The Report on the implementation of the "Circular Economy Action Plan (SDW (2019)90)" [4] supporting the transition towards a "Circular economy and a zero waste programme for Europe (COM(2014)398)" [5] are also key in guiding the future of the raw materials sector. More specifically, the "Report on Critical Raw Materials and the Circular Economy" [6] highlights the importance of adapting to changes brought on by the transition to a low-carbon and more circular economy, as well as the strategic importance of raw materials for the EU manufacturing industry.

In this sense, ERA-MIN addresses all parts of the raw materials values chain defined in the EC Communication Circular Economy [7], and the Circular Economy, Closing the loop. "An ambitious EU Circular Economy Package" [8] as shown in Figure 1.

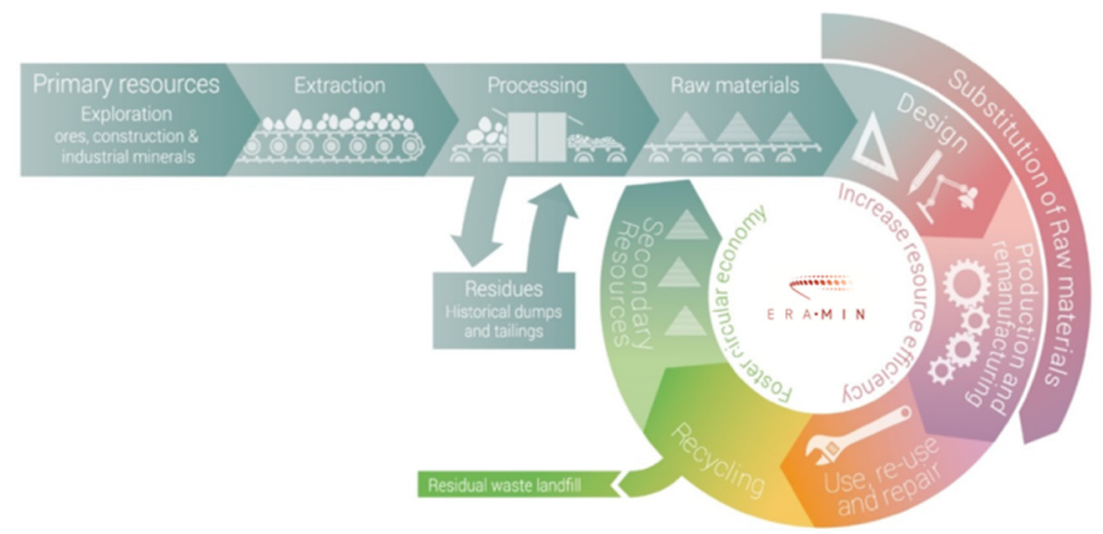

Figure 1. The ERA-MIN view of RM within Circular Economy [9]. 
In addition, the European Commission, in the communication "A clean planet for all" [10], has also defined a set of seven main strategic priorities considering new and improved materials for buildings, reduction of materials through re-use and recycling, substitution of carbon intensive materials, biogenic materials as well as more efficient and sustainable batteries, one of the key sectors clearly dependent on a sustained supply of raw materials. Furthermore, the "European Green Deal" [11] designs a set of deeply transformative policies, which include new forms of collaboration with industry and investments in strategic value chains aiming to mobilise industry towards a clean and circular economy.

Finally, it is worth highlighting two specific initiatives which are closely interrelated with the ERA-MIN goals: the European Innovation Partnership on Raw Materials (EIP RM) [12] and the European Institute of Innovation and Technology for Raw Materials (EIT RM) [13]. The EIP RM is a multi-stakeholder platform launched by the EC whose main objective is to help raise industry's contribution to the EU's GDP to around $20 \%$ by 2020 by securing its access to raw materials. Since its launch, the EIP has held annual high-level conferences where the calls for Raw Materials Commitments, including ERA-MIN calls were announced. ERA-MIN 2 was a member of the High-level Steering Group of the EIP RM for the period 2017-2020 and takes very careful consideration of the EIP RM recommendations for the establishment of the priorities of its calls for proposals. ERA-MIN 2 was also a member of the EU-Canada Raw Materials Stakeholders Forum Steering Committee to inform the governmental EU-Canada Bilateral Dialogue on Raw Materials under the CETA agreement.

The EIT RM is a body of the EU which brings together 115 research performing organisations from 22 EU MS, making it the biggest consortium of this kind in the world. The EIT RM addresses challenges in the area of RM (sustainable exploration, extraction, processing, recycling, and substitution) and integrates multiple disciplines, diversity and complementarity along the three sides of the knowledge triangle (business, education and research) and across the whole RM value chain. ERA-MIN will cooperate with EIT RM to foster possible synergies and complementarities.

\section{ERA-MIN, the Pan-European Network on Raw Materials}

\subsection{FP7 ERA-NET ERA-MIN}

ERA-MIN (2011-2015) was an ERA-NET on the "Industrial Handling of Raw Materials for European industries" that was launched in November 2011 coordinated by CNRS (France). It was supported by the FP7 and aimed at setting up networks and mechanisms to foster coordinated research in the field of industrial production and supply of non-energy and non-agricultural raw materials, in line with the "EU Raw Materials Initiative". To achieve this objective, ERA-MIN conducted three main tasks:

1. Mapping and networking of the European non-energy mineral raw materials research community;

2. Defining research priorities;

3. Implementing the research actions and European research programs financed by the fifteen national and public funding agencies involved in ERA-MIN.

ERA-MIN consortium was enlarged to fifteen EU countries and two non-EU countries (Argentina and South Africa). In 2013 the ERA-MIN Research Agenda [14] was published aiming to list the most important challenges and priorities of research and innovation identified and discussed by 150 experts from the academic and industrial sectors during the year 2012. This document addressed issues covering the whole value chain of non-energy, non-agricultural raw materials, and it tries to maintain a comprehensive vision including both the industrial and academic points of view. The ERA-MIN Research Agenda (2013) was written by the leaders of the five working groups that were set up by ERA-MIN in February 2012 and have informed the thematic areas of the two Joint Transnational Calls (2014 and 2015) of ERA-MIN. It was also one of the background documents of the Strategic Implementation Plan (SIP) of the EIP RM in 2013 as well as the background of the definition 
of the Joint Transnational Calls (2017, 2018 and 2019) of the following programme ERA MIN 2 scope and topics.

Three Joint Transnational Calls (JTC) were launched under ERA-MIN from 2013 to 2015, one per year. A total of 17 multidisciplinary transnational projects were funded under these three JTC, with a public funding of $€ 13$ million ( $€ 19$ million of total projects costs). Thirteen projects on primary resources addressed the first part of the loop "From exploration to mine closure and rehabilitation", seven projects on secondary resources and two projects on substitution of CRM were funded under the ERA-MIN JTCs. The ERA-MIN funded R\&I projects have successfully contributed to develop the raw materials community in Europe and beyond, in line with the objectives of the SIP of EIP RM. Moreover, the analysis of the Calls 2014 and 2015 showed significant cooperation within EU countries and also with Argentina and South Africa in the non-energy and non-agricultural raw materials sectors, from exploration, extraction, mineral processing and metallurgy to recycling of mining and smelting residues and substitution of critical materials for green energy technologies. Moreover, the enterprises in the mining sector and in the recycling sector are cooperating mainly through academia-industry partnerships [15].

\subsection{H2020 ERA-NET ERA-MIN 2}

ERA-MIN 2 (2016-2022) is an ERA-NET Cofund P2P project co-funded under Horizon 2020. ERA-MIN 2 "Implement a European-wide coordination of research and innovation programs on raw materials to strengthen the industry competitiveness and the shift to a circular economy" aims to implement a Research \& Innovation Programme on Raw Materials to Foster Circular Economy in line with the integrated strategy proposed in the EU Raw Materials Initiative, the SIP of the EIP RM as well as with the EIT Raw Materials3 to offer complementary support and avoid duplication of efforts. ERA-MIN 2 addresses four key objectives:

1. Support and promote R\&I cooperation in Europe.

2. Reduce fragmentation of R\&I funding in the area of non-energy non-agricultural raw materials across Europe and globally.

3. Provide a pan-European support network and financial resources to improve synergies, coordination and collaboration.

4. Improve the efficiency and impact of human and financial investment in R\&I activities in the area of Raw Materials.

The ERA-MIN 2 consortium (Figure 2) consists of 21 funding organisations from 18 countries/regions (13 EU MS countries/regions, one Associated country, and four non-EU countries).

Three Joint Transnational Calls have been launched under ERA-NET ERA-MIN 2: one co-funded call in 2017 and two additional calls in 2018 and in 2019 only with national/regional funds. ERA-MIN 2 has built a strong global network with the European raw materials players, as well as with non-European stakeholders. Seven funding organisations from EU MS regions (Brussels, Wallonia, Calabria), EU MS countries (Czech Republic, Greece, Slovakia) and non- EU Québec province have joined one, or two calls.

A total of 40 multidisciplinary projects were funded under the ERA-MIN 2 calls, with $€ 29$ million of public funding ( $€ 41$ million of total projects costs). All the thematic areas, based on challenges and priorities identified in the ERA MIN Research Agenda as well as in the SIP of EIP RM, were covered (Figure 3). Topic 1. Exploration and mining is addressed by 10 projects, topic 2 . Design is addressed by 17 projects, topic 3 . Processing, production and remanufacturing is addressed by 26 projects, topic 4 . Recycling and re-use of End-of-Life products is addressed by 24 projects and topic 5 . Cross cutting issues is addressed by 23 out of the 40 projects funded in the 2017, 2018 and 2019 calls. Moreover, up to now, a decade since the first ERA-MIN, a total of 57 R\&I projects were supported with $€ 42$ million of public funding ( $€ 60$ million of total projects costs), 34\% (average) private sector [16], which cover the whole raw materials innovation chain and contributed successfully for the ERA-MIN Research Agenda challenges and priorities and the Technology Pillar of the 
EIP RM's SIP. Eight battery related projects addressing raw materials supply for batteries or recycling of end-of-life batteries were supported with $€ 6$ Million of public funding in previous ERA-MIN Calls (2015, 2017, 2018 and 2019).

\section{CONSORTIUM}

Pan-European network of 21 public research and innovation funding organisations from:

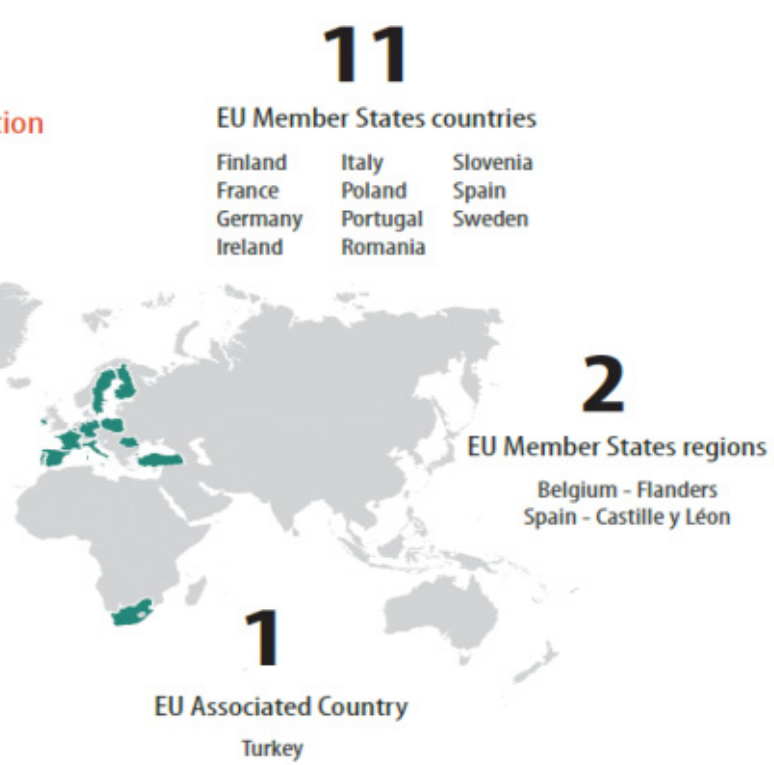

Figure 2. ERA-MIN 2 consortium of funding organisations-countries/regions (FCT-Portugal; Vinnova-Sweden; JULICH—Germany; UEFISCDI-Romania; MINECO—Spain; MINCyTArgentina; NCBR—Poland; CONICYT_Chile; MIZS—Slovenia; ANR_France; CDTI—Spain; DST— South Africa; GSI-Ireland; ADEME_France; TUBITAK—Turkey; Tekes-Finland; HermesfondsBelgium/Flanders; ADE-Spain/Castilla y Léon; FWO-Belgium/Flanders; MIUR-Italy; Finep-Brazil).

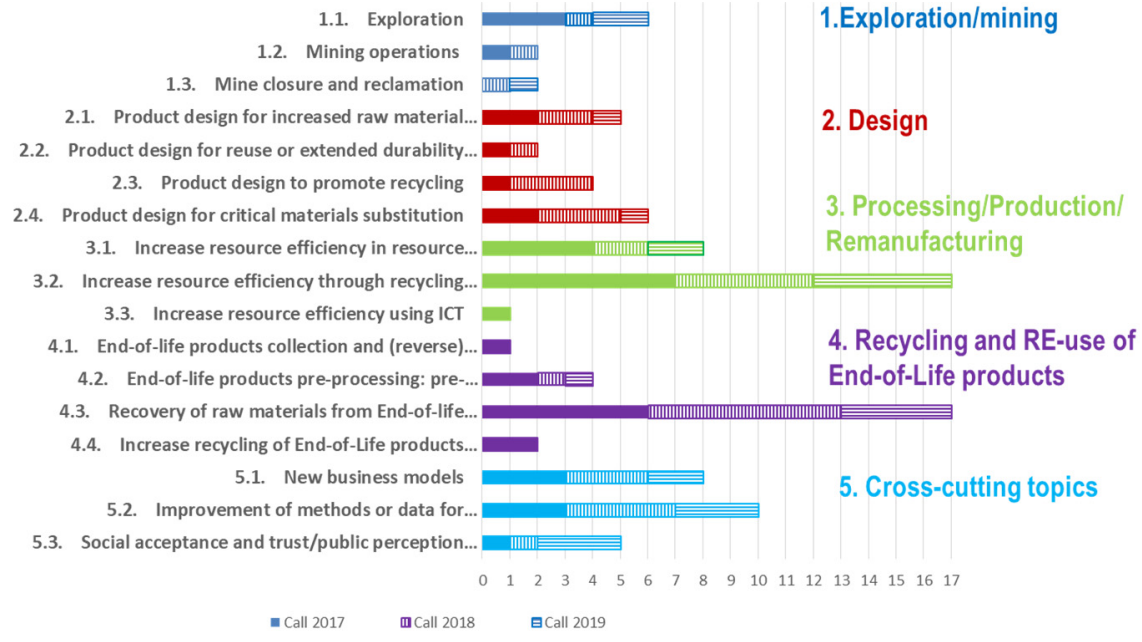

Figure 3. Sub call topics addressed by funded projects of the 2017, 2018 and 2019 JTCs in ERA-MIN 2. Please be aware that projects may address more than one subtopic.

\subsection{H2020 ERA-NET ERA-MIN3}

ERA-MIN3 (2020-2025), started officially on 1 December 2020, is a global, innovative and flexible pan-European network of 24 research funding organisations, supported by EU Horizon 2020 under the ERA-NET Cofund scheme. It aims to continue strengthening the mineral raw materials community through the coordination of research and innovation programmes on non-fuel and non-food raw materials (metallic, construction, and industrial minerals). Its five key objectives are: 
1. Contribute to the objectives and the implementation of both the RMI and the EIP RM Strategies, particularly in the priority area of RM R\&I coordination, maximising the impact of other actions in the Technology Pillar of the SIP;

2. Reduce fragmentation of RM R\&I funding in the area of non-energy, non-agricultural raw materials across Europe and globally;

3. Improve synergy, coordination and coherence between regional, national and EU funding in the non-energy, non-agricultural RM research fields through transnational and international collaboration;

4. Improve use of human and financial resources in the area of non-energy, non-agricultural RM research and innovation;

5. Improve the competitiveness and the environmental, health and safety performance of non-energy, non-agricultural RM operations.

The ERA-MIN3 consortium consists of 24 funding organisations from 15 EU MS countries, 3 EU MS regions, 1 Associated country and 2 non-EU countries. Québec province in Canada, Bulgaria, Czech Republic, Estonia, Slovakia, Wallonia in Belgium and Navarra in Spain joined the ERA-MIN3 network for the first time although Czech Republic, Fonds de recherche du Québec-Nature et technologies (Québec province), Slovakia, Wallonia have associated to previous ERA-MIN2 Calls 2008 and/or 2019 (Figure 4). Finep (Brazil) is willing to become a partner of ERA-MIN3 consortium without joining the Call 2021.

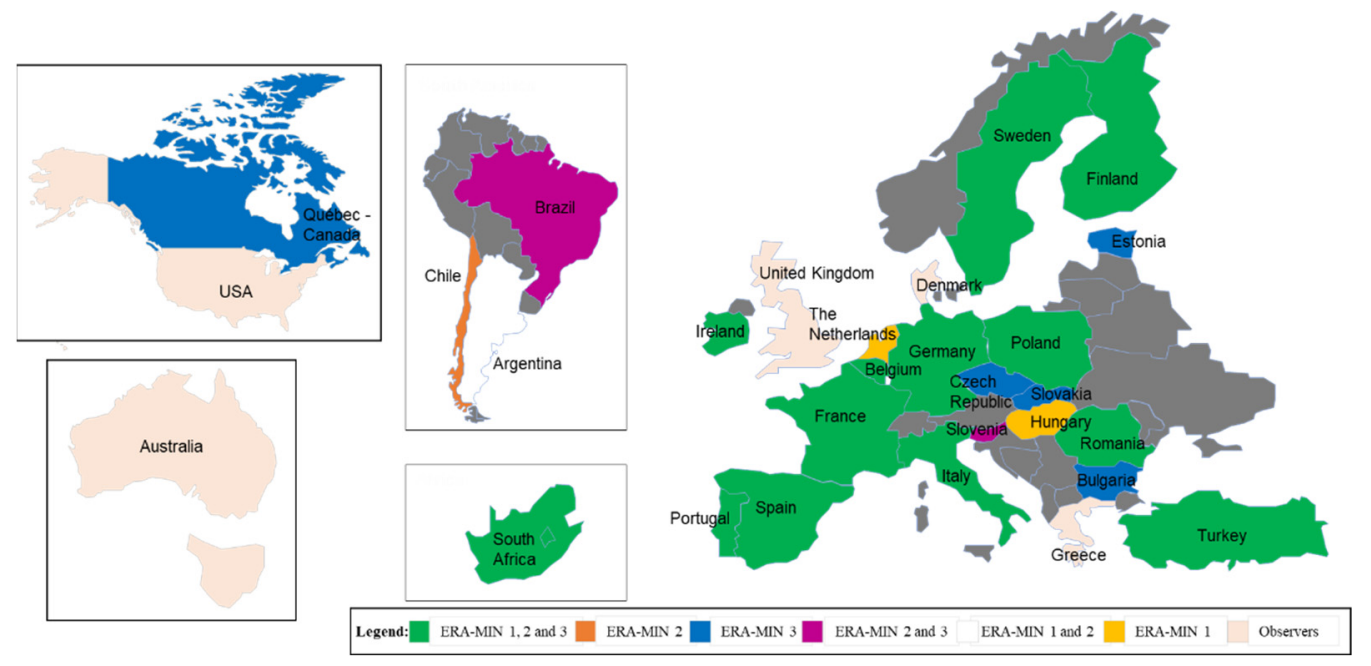

Figure 4. ERA-MIN network evolution (2011-2021). The ERA-MIN 3 consortium of funding organisations-countries/regions (Hermesfond-Belgium/Flanders; FWO-Belgium/Flanders; SPW-Belgium/Wallonia; BNSF_Bulgaria; TA CR-Czech Republic; Business Finland-Finland; ETAg_Estonia; ADEME-France; ANR_France; JÜLICH—Germany; GSI_Ireland; MUR_Italy; NCBR_Poland; FCT_Portugal; UEFISCDI_Romania; CDTI—Spain; CFNA—Spain/Navarra; AEISpain; SAS—Slovakia; MIZS—Slovenia; Vinnova—Sweden), one EU Associated country (TUBITAKTurkey), and two non-EU countries (PRIMA-Québec-Canada; DSI—South Africa).

Subsequently to ERA-MIN 2, FCT representing ERA-MIN 3 is now a member of the High-level Steering Group of the EIP RM for the period 2021-2024.

ERA-MIN3 will launch at least two JTCs for transnational R\&I proposals to support peer-reviewed excellent transnational R\&I projects on non-fuel and non-food raw materials (metallic, construction, and industrial minerals). The EU Co-funded ERA-MIN Joint Call 2021 [17] is the first joint call of the ERA-NET Cofund ERA-MIN3, officially launched on the 15 January 2021, which counts with an indicative budget of $€ 19.5$ Million. In terms of pre-proposal submission, the EU co-funded ERA-MIN Joint Call 2021 has been the most successful call of ERA-MIN to date, with 146 pre-proposals submitted by deadline and 892 applicants participating (of which $32 \%$ are enterprises), requesting funding to the 24 participating countries/regions of the call [18]. Moreover, nine associated partners 
in pre-proposals, including four enterprises, were from other EU and non-EU countries, namely, Alberta province in Canada, Austria, Greece, Morocco, Norway, Peru, United Kingdom and USA. When comparing with the EU co-funded Call 2017 of ERA-MIN 2, the thematic area most addressed in ERA-MIN 3 Call 2021 was Recycling whereas in 2017 was Production which shows an increased interest of the RM research community towards Recycling topics in line with the current EU Raw Materials Policies.

A second joint call for transnational R\&I proposals is planned in 2023 supported with national and regional funds only and funding organisations from other EU and non-EU countries or regions are invited to associate and commit national/regional funds to support their institutions (universities and/or enterprises) in international consortia thus promoting access to new knowledge as well as to new markets world-wide.

\section{ERA-MIN3 the Continuation towards a European Partnership}

In parallel to the conclusion of the ERA-MIN 2 project, ERA-MIN3 aims to sustain for the following five years, the efforts and structures built on the back of the network and bridge what is one of the last ERA-NETs with the upcoming European Partnerships. Continuing on the Commission's plan for a new ERA based on excellence: The EC communication "A new ERA for Research and Innovation" [19] defines several strategic objectives for the last ERA-NET Cofund to which ERA-MIN3 will contribute:

1. prioritise investments and reforms in research and innovation, to support the digital and green transition and Europe's recovery;

2. improve access to excellent R\&I for researchers across the EU;

3. translate results into the economy to ensure market uptake of research output and Europe's competitive leadership in technology;

4. make progress on the free circulation of knowledge, researchers and technology through stronger cooperation with EU countries.

To make the European Research Area stronger, national research and innovation policies will continue to be strengthened too, and in this sense, ERA-MIN3 will continue to organise, besides the two JTCs for R\&I projects in the raw materials, additional activities to build further bridges with other funding organisations, EU funded projects and other stakeholders in the non-fuel, non-food raw materials sector and across the world.

As a continuation of the ERA-NETs, the new policy approach on European Partnerships and the rationalisation and reform of the partnership landscape that started in 2019 mark the change from Horizon 2020 to Horizon Europe. Having started in 2020, the transition to the European Partnerships scheme in the raw materials sector will take place from 2025 onwards. Under the first co-funded call, the ERA-MIN3's funded R\&I projects are planned to start in May 2022 and will run all the way until mid-2025, right before the end of the ERA-MIN3 project. The second call, expected for 2023, will bridge the end of the ERA-MIN network as we know it, with its new embodiment into the European Partnerships with its continued goals to support the circularity, sustainability and leadership of the European and worldwide non-fuel, non-food raw materials sector.

Author Contributions: Conceptualization, J.S. and J.M.; methodology, J.S. and J.M.; software, Not Applicable.; validation, D.C., J.S. and J.M.; formal analysis, D.C. and J.M.; investigation, J.S. and J.M.; data curation, D.C., J.S. and J.M.; writing-original draft preparation, J.S. and J.M.; writing-review and editing, D.C., J.S. and J.M.; visualization, D.C., J.S. and J.M.; supervision, D.C. and J.M.; project administration, D.C.; funding acquisition, D.C.. All authors have read and agreed to the published version of the manuscript.

Funding: ERA-MIN has received funding from the European Union's Horizon 2020 Research and Innovation Programme under grant agreements No. 730238 (ERA-MIN 2) \& No. 101003575 (ERA-MIN3).

Institutional Review Board Statement: Not applicable.

Informed Consent Statement: Not applicable. 
Data Availability Statement: Not applicable.

Conflicts of Interest: The authors declare no conflict of interest.

\section{References}

1. ERA-LEARN 2020-15 Years of European Public-Public Partnerships in Research \& Innovation. Available online: https:/ /www. era-learn.eu/documents/era-learn-publications/era-learn-15-yr-brochure-aw2-web.pdf (accessed on 2 December 2021).

2. "Raw Materials Initiative-Meeting our Critical Needs for Growth and Jobs in Europe" COM (2008) 699 Final. Available online: https: / / eur-lex.europa.eu/legal-content/EN/TXT/PDF/?uri=CELEX:52008DC0699\&from=EN (accessed on 13 December 2021).

3. Transforming Our World: The 2030 Agenda for Sustainable Development. Available online: https://sdgs.un.org/2030agenda (accessed on 26 May 2021).

4. Report from the Commission to the European Parliament, the Council, the European Economic and Social Committee and Committee of the Regions on the Implementation of the Circular Economy Action Plan. Available online: https: / / ec.europa.eu/ commission/publications/report-implementation-circular-economy-action-plan-1_de (accessed on 19 May 2021).

5. “Towards a Circular Economy: A Zero Waste Programme for Europe" COM (2014) 398 Final. Available online: https://eurlex.europa.eu/resource.html?uri=cellar:50edd1fd-01ec-11e4-831f-01aa75ed71a1.0001.01/DOC_1\&format=PDF (accessed on 29 April 2021).

6. Commission Staff Working Document Report on Critical Raw Materials and the Circular Economy. Available online: https: / / ec.europa.eu/docsroom/documents/27327 (accessed on 19 May 2021).

7. European Commission. Closing the Loop - An EU Action Plan for the Circular Economy; COM (2015) 614/2; European Commission: Brussels, Belgium, 2015.

8. Circular Economy Closing the Loop: An Ambitious eu Circular Economy Package. Available online: https://ec.europa.eu/info/ publications/ambitious-eu-circular-economy-package_en (accessed on 24 May 2021).

9. $\quad$ ERA-NET. Available online: https://www.era-min.eu/ (accessed on 24 January 2021).

10. Communication from the Commission to the European Parliament, the European Council, the Council, the European Economic and Social Committee, the Committee of the Regions and the European Investment Bank a Clean Planet for All a European Strategic Long-Term Vision for a Prosperous, Modern, Competitive and Climate Neutral Economy COM/2018/773 Final. Available online: https:/ / eur-lex.europa.eu/legal-content/EN/TXT/?uri=CELEX:52018DC0773 (accessed on 22 May 2021).

11. Communication from the Commission to the European Parliament, the European Council, the Council, the European Economic and Social Committee and the Committee of the Regions. Available online: https:/ / ec.europa.eu/info/sites/info/files/europeangreen-deal-communication_en.pdf (accessed on 30 April 2021).

12. Available online: https:/ / ec.europa.eu/growth/sectors/raw-materials/eip_en (accessed on 22 May 2021).

13. Available online: https:/ / eitrawmaterials.eu/ (accessed on 22 May 2021).

14. Vidal, O.; Weihed, P.; Hagelüken, C.; Bol, D.; Christmann, C.; Arndt, N. ERA-MIN Research Agenda. 2013. Available online: https://www.era-min.eu/sites/default/files/publications/era-min_research_agenda.pdf (accessed on 10 October 2021).

15. Carrilho, D. Stepping up the international cooperation for the sustainable supply of raw materials. Eur. Geol. J. 2016, 42, 33-36. Available online: https:/ / eurogeologists.eu/ european-geologist-journal-42-stepping-up-the-international-cooperation-for-thesustainable-supply-of-raw-materials / (accessed on 12 October 2021).

16. Calls Results. Available online: https:/ / www.era-min.eu/results (accessed on 13 December 2021).

17. More Information on the EU Co-Funded ERA-MIN Joint Call 2021. Available online: https://www.era-min.eu/joint-call/eramin-joint-call-2021 (accessed on 17 October 2021).

18. More Information on the Pre-Proposal Submission Results of the EU Co-Funded ERA-MIN Joint Call 2021. Available online: https: / / www.era-min.eu/results (accessed on 18 October 2021).

19. Communication from the Commission to the European Parliament, the Council, the European Economic and Social Committee and the Committee of the Regions A New ERA for Research and Innovation. Available online: https:/ / eur-lex.europa.eu/legalcontent/EN/TXT/?uri=COM\%3A2020\%3A628\%3AFIN (accessed on 20 October 2021). 